ЗИННАТУЛЛИНА Гулюза Ильфатовна - кандидат исторических наук, старший преподаватель кафедры гуманитарных и общенаучных дисииплин Тюменского высшего военно-инженерного командного училища им. маршала инженерных войск А.И. Прошлякова (625001, Россия, г. Тюмень, ул. Л. Толстого, 1; Zgulyusa@gmail.com)

ДАВЛЕТШИНА Кристина Юрьевна - кандидат педагогических наук, доцент кафедры русского языка Тюменского высшего военно-инженерного командного училища им. маршала инженерных войск А.И. Прошлякова (625001, Россия, г. Тюмень, ул. Л. Толстого, 1; Milana_Kris_1991@таil.ru)

\title{
К ВОПРОСУ ОБ ИССЛЕДОВАНИИ ПРОБЛЕМ СОЦИОКУЛЬТУРНОЙ АДАПТАЦИИ ИНОСТРАННЫХ КУРСАНТОВ В ВОЕННЫХ ВУЗАХ РОССИЙСКОЙ ФЕДЕРАЦИИ
}

Аннотация. Статья посвящена актуальной проблеме адаптации иностранных военнослужащих в условиях российских военных учебных заведений. На основе анализа работ, посвященных данной проблематике, авторы обосновывают актуальность комплексного исследования социокультурной среды военного вуза и оптимизации процесса социокультурной адаптации.

Ключевые слова: социокультурная адаптация, иностранные военнослужащие, образовательная среда, социологическое исследование, мониторинг, оптимизация процесса адаптации

$\mathrm{P}$ оссийские военные вузы, отвечая требованиям современного высшего образования, активно интегрируются в мировое образовательное сообщество. Одним из важных направлений военно-технического сотрудничества Министерства обороны РФ с зарубежными странами является профессиональная подготовка иностранных военнослужащих в российских военных вузах.

В последние годы в ходе реформирования военного образования доля иностранных курсантов в российских военных вузах значительно возросла. Этому способствует и тот факт, что российское военное образование является престижным в ряде стран-союзников. Соответственно, возрастает ответственность российского образования за качество образовательных услуг, оказываемых иностранным гражданам, обучающимся в военных вузах.

Успешность профессиональной подготовки иностранных военнослужащих, а следовательно профессиональное становление будущих офицеров во многом определяется эффективностью их социально-психологической адаптации в российских военных вузах, где существует особая по сравнению с гражданским вузом система организации учебно-воспитательного процесса.

Специфика социальной адаптации иностранных обучающихся заключается еще и в том, что, кроме включенности в учебный процесс, иностранные курсанты выполняют военно-профессиональные обязанности, связанные с необходимостью строго соблюдать установленный распорядок дня, безоговорочно подчиняться уставу, приказам и т.п.

Особенностью военного образования является то, что в связи с военно-технической необходимостью и существующими контрактно-договорными обязательствами сторон иностранные военнослужащие лишены возможности выбора вуза обучения. Попадая в военное учебное заведение, иностранные курсанты взаимодействуют не только с представителями своего этноса, но и военнослужащими других стран, которые являются представителями иных религиозных конфессий и культур [Бучнева 2015: 206-207]. 
Таким образом, в процессе погружения в образовательную среду военного вуза и в новое культурное пространство иностранные курсанты преодолевают ряд трудностей и проблем, связанных с адаптацией к новым условиям обучения и проживания. Успешная адаптация курсантов способствует их быстрому включению в учебный процесс, что позволяет решить проблему сохранения контингента учащихся, который может существенно сократиться в процессе обучения. Кроме того, эффективная адаптация в значительной степени может повысить уровень и качество обучения иностранных военнослужащих, обеспечивая высокую заинтересованность в получении всех необходимых компетенций. Такие показатели, как академическая успеваемость, научная и общественная активность, являясь показателями эффективности воспитания и обучения, воспринимаются и как факторы успешной адаптации. В свою очередь, плохая успеваемость, отсутствие интереса к общественной жизни учебного заведения позволяют говорить о трудностях адаптационного процесса.

Проблемам адаптации иностранных обучающихся посвящено много научных трудов, в которых достаточно подробно рассмотрены различные аспекты, факторы, барьеры, этапы и критерии адаптации. Так, исследователи выделяют психофизиологическую, социально-психологическую, социокультурную, педагогическую и академическую адаптацию [Бесценная, Федяева 2020; Гурьянчик, Макеева 2018].

Благодаря своей многоаспектности, адаптация является предметом, находящимся на стыке нескольких наук о человеке: социологии, философии, педагогики, социальной психологии, медицины и др. [Власова 2009]. Кроме того, являясь результатом установления и коррекции взаимоотношений между личностью и социальной средой, вхождения личности в новую для нее культуру, успешная адаптация неразрывно связана с возможностями оптимизации психолого-педагогической и социально-культурной помощи.

Наиболее актуальным аспектом в этой связи является оптимизация социокультурной адаптации. Опыт исследований ученых показывает, что социокультурная среда имеет важное значение на начальных этапах адаптации. Человек, попадая в новую социокультурную среду, формирует мнение о стране, людях, культуре исходя из первого впечатления - наиболее сильного и устойчивого. Некоторые исследователи справедливо полагают, что социокультурная адаптация идет по двум путям: это адаптация к российской культурной среде (внутри института и вне его) и адаптация к национальным культурам курсантов, обучающихся на одном курсе и проживающих совместно (казарма, общежитие) [Бесценная, Федяева 2020]. Большое внимание в работах исследователей уделяется классификации факторов социокультурной адаптации. Так, выделяют индивидуальные и групповые, ситуационные факторы, комплекс материальных, духовных и личных факторов, а также факторы, зависящие от курсантов и преподавателей, и др.

Т. Павлушкина определяет адаптацию иностранных военнослужащих как сложный многофакторный процесс, детерминированный национальными, культурными, индивидуально-личностными особенностями, с одной стороны, и связанный с влиянием внешних факторов на них - с другой. Обобщая многообразие подходов в изучении факторов влияния на адаптацию иностранных военнослужащих, она предложила пространственную модель адаптирующих воздействий на иностранных военнослужащих в российском военном вузе, состоящую из двух модулей: внутреннего и внешнего [Павлушкина 2014б: 61-62]. Внутренний модуль представлен личностью иностранного военнослужащего с его национальными, культурными, религиозными и индивидуальноличностными особенностями (уровень знания русского языка, базовой подго- 
товки, индивидуальная способность к обучению, уровень мотивации, тревожности).

Внешний модуль представлен системой факторов на разных уровнях. Первый - микроуровень - показывает возможности влияния социокультурной и образовательной среды военного вуза на процесс адаптации иностранных военнослужащих; второй - макроуровень - представлен социокультурной инфраструктурой окружающей среды; третий - мегауровень - представлен российским обществом с самобытной многонациональной культурой, ценностными представлениями, морально-психологическим духом и менталитетом [Павлушкина 2014б: 62].

Основным препятствием для успешной адаптации иностранных курсантов к образованию, проживанию и ведению службы в России являются различные адаптационные барьеры. Термин «языковой барьер» часто встречается в работе преподавателей с иностранными военнослужащими, однако толкование этого понятия остается расплывчатым. Скорее всего, причина этого - наличие смежных барьеров, которые встречаются при изучении русского языка. Так, исследователи выделяют наиболее характерные барьеры, возникающие у образовательных мигрантов: языковой барьер, препятствующий усвоению учебной информации и общению; приспособление к новой социокультурной среде, недостаток знаний у иностранных граждан о стране пребывания; психофизиологические трудности, связанные со сменой климата, питания, режима и т.д.; адаптация иностранных курсантов к образовательной среде военного вуза, а также низкий уровень информированности о политической, экономической и социально-культурной жизни России и др. [Гурьянчик, Макеева 2019].

Среди основных проблем первого года обучения исследователи называют в первую очередь языковой, межкультурный и академический барьеры.

В.Л. Бернштейн определяет языковой барьер «трудными ситуациями общения, возникающими как следствие незнания основных правил и норм межличностного общения; незнания особенностей культуры страны изучаемого языка; неумения неподготовленного речепорождения на иностранном языке; неподготовленности к самому факту существования трудностей межкультурного общения» [Бернштейн 2005]. Можно сделать вывод, что языковой барьер - это невозможность курсанта активизировать языковые знания, которыми он владеет, для создания коммуникации с преподавателем, военнослужащими, другими людьми. Психологический характер барьера проявляется в невозможности выразить свои мысли при наличии набора соответствующих лингвистических знаний. А лингвистический барьер проявляется в том, что военнослужащим не хватает набора знаний грамматических правил, словарного запаса для выражения своих мыслей.

Ученые отмечают, что примерно через 3 месяца пребывания у иностранцев наступает культурный шок - они начинают противопоставлять свою культуру тому, что видят в России, а некоторые факты российской действительности вызывает непонимание, агрессию, перерастающую затем в апатию. Поэтому на 1-м курсе им важно оказывать педагогическую и психологическую поддержку.

По мнению ученых, данная проблема требует более глубокого социопсихологического исследования, на основе которого можно будет выработать рекомендации для педагогического процесса. В этом случае педагогическое сопровождение является специально организованной деятельностью всех субъектов учебно-воспитательного процесса для решения проблем и трудностей иностранных военнослужащих, возникающих при вхождении ими в новую поликультурную среду военного вуза, направленной на развитие у них навыков 
учебной самоорганизации, активизацию личностного и профессионального саморазвития [Павлушкина 2014а].

В оптимизации социокультурной адаптации иностранных курсантов немаловажную роль играет поликультурная компетентность преподавателей, кураторов учебных групп. Они должны не только обладать знаниями культурных, религиозных традиций и стереотипов поведения, принятых в обществах, из которых прибыли их подопечные, но практически применять свои знания при работе с курсантами [Поздняков 2010].

На сегодняшний день сотрудники вузов наработали обширный опыт практической работы, направленной на создание условий успешной социокультурной адаптации иностранных военнослужащих. Несмотря на это, в российских вузах образовательная среда еще не в полной мере адаптирована к обучению иностранцев; соответственно, актуальность проведения периодических исследований социокультурной адаптации иностранных курсантов сохраняется.

Одним из условий обеспечения успешной адаптации будущих иностранных военных специалистов будет являться систематическое исследование процессов социокультурной адаптации иностранных курсантов с учетом особенностей военного вуза как образовательной среды, выявление как типичных затруднений, испытываемых иностранными курсантами-первокурсниками в ходе адаптации, так и потенциальных возможностей для ее успешного прохождения.

Таким образом, организация адаптационной поддержки иностранных курсантов должна стать комплексной системной работой военного вуза, которая состоит из нескольких этапов:

- социологического исследования с учетом этнопсихологических и возрастных показателей обучающихся иностранных курсантов;

- разработки методических рекомендаций (на основе показателей социологического опроса) для профессорско-преподавательского и офицерского состава вуза, работающих с иностранными курсантами;

- разработки комплекса мероприятий учебно-воспитательной работы (использование этнокультурного компонента в образовательном процессе в ходе изучения отдельных дисциплин и организации досуга иностранных военнослужащих с учетом регионального потенциала).

Периодический мониторинг уровня социокультурной адаптации иностранных курсантов позволит сравнить опыт прошлых лет и покажет динамику уровня социокультурной среды вуза.

Хорошо отлаженный процесс социокультурной адаптации иностранных студентов способствует большей эффективности обучения, получению предполагаемых компетенций, что, в свою очередь, может способствовать не только сохранению квоты на обучение иностранцев, но и ее увеличению, а также повысить имидж учебного заведения в мировом сообществе.

Статья подготовлена при финансовой поддержке Российского научного фонда, проект № 17-78-20149 в рамках работы Школымолодогоэтнополитологав Республике Башкортостан.

\section{Список литературы}

Бернштейн В.Л. 2005. Пути формирования межкультурной коммуникативной компетенции на уроке иностранного языка. - Преподавание иностранных языков и культур: проблемы, поиски, решения. Лемпертовские чтения-VII: материалы международного научно-методического симпозиума. Пятигорск. C. 48-49.

Бесценная В.В., Федяева Е.В. 2020. Адаптация иностранных курсантов в 
военном вузе РФ: что труднее всего? - Наука и воинская безопасность. № 1. C. $163-170$.

Бучнева О.А. 2015. Особенности социокультурной адаптации иностранных курсантов-первокурсников к образовательной среде военного вуза. Инновационная наука. № 12-2. С. 205-208.

Власова Т.А. 2009. Социально-психологическая адаптация студентов младших курсов к условиям обучения в вузе. - Вестник Челябинского государственного педагогического университета. № 1. С. 13-22.

Гурьянчик В.Н., Макеева Т.В. 2018. Социокультурная адаптация иностранных курсантов военных вузов. - Социс. Социологические исследования. № 11. С. 124133.

Гурьянчик В.Н., Макеева Т.В. 2019. Иностранная образовательная миграция в контексте межкультурной коммуникации: военно-социальный аспект. Российский университет в неустойчивом мире: глобальные вызовы и национальные ответы: материалы национальной научно-практической конференции. Ч. 2. C. 224-231.

Павлушкина Т.В. 2014а. Модель педагогического сопровождения адаптации иностранных военнослужащих в российском военном вузе. - Теория и практика общественного развития. № 11. С. 66-69.

Павлушкина Т.В. 2014б. Факторы адаптации иностранных военнослужащих в военном вузе. - Теория и практика общественного развития. № 12. С. 61-64.

Поздняков И.А. 2010. Проблемы адаптации иностранных студентов в России в контексте педагогического сопровождения. - Известия РГПУ им. А.И. Герцена. № 121. С. 161-167.

ZINNATULLINA Gulyuza Ilfatovna, Cand.Sci. (Hist.), Senior Lecturer of the Chair of Humanities and General Scientific Disciplines, Tyumen Higher Military Engineering Command School named after Marshal of the Engineering Troops A.I. Proshlyakov (1 Tolstogo St, Tyumen, Russia, 625001; Zgulyusa@gmail.com)

DAVLETSHINA Kristina Yur'evna, Cand.Sci. (Ped.), Senior Lecturer of the Chair of Russian Language, Tyumen Higher Military Engineering Command School named after Marshal of the Engineering Troops A.I. Proshlyakov (1 Tolstogo St, Tyumen, Russia, 625001; Milana_Kris_1991@mail.ru)

\section{ON THE STUDY OF THE PROBLEMS OF SOCIO-CULTURAL ADAPTATION OF FOREIGN CADETS IN MILITARY UNIVERSITIES OF THE RUSSIAN FEDERATION}

\footnotetext{
Abstract. The article is devoted to the actual problem of adaptation of servicemen of the armed forces of foreign states in conditions of Russian military educational institutions. Based on the analysis of works devoted to this issue, the paper substantiated the urgency of a comprehensive study of the socio-cultural environment of a military university and the optimization of the process of sociocultural adaptation.
}

Keywords: socio-cultural adaptation, servicemen of armed forces of foreign states, educational environment, sociological research, monitoring, optimization of adaptation process 